\title{
MAKNA DAN TRANSMISI MANTRA PEMANGGILAN ARWAH KESENIAN JAWA BANTENGANDAERAH MBURING MALANG JAWA TIMUR
}

\author{
MUHAMAD NASHICHUDDIN ${ }^{1}$, MUHAMMAD G. R. ${ }^{2}$, dan PATRIA LIFCA P. ${ }^{3}$ \\ Prodi PBSI, FKIP, Universitas Muhammadiyah Malang \\ nasehudin.umm@gmail.com ${ }^{1}$, rifkigibravil@gmail.com² ${ }^{2}$,patrialifcap@gmail.com
}

\begin{abstract}
Abstrak
Penelitian ini mendeskripsikan makna dan fungsi secara mendalam dari mantra pertunjukan Bantengan yang berasal dari Mojokerto Jawa Timur Struktur. Mantra ditutupi dengan rumus mistis, magis, mitologi, suara, diksi, dan imajinasi. Wacana nilai Islam telah sangat dominan dalam bahasa Mantra Bantengan. Zat bahasa Arab juga dilekatkan dalam teks Mantra Bantengan dan menghasilkan bentuk karakteristik khusus yang baru. Latar belakang permasalahannya yaitu apa fungsi dan makna agar masyarakat dan para khalayak ramai mengetahui dari mantra tersebut, apa yang dimaksud dengan fungsi ritual, Penelitian ini menggunakan metode penelitian kualitatif dengan pendekatan simiotika milik Roland Barthes sebagai acuan makna mantra dari kesenian Bantengan, bagaimana perkembangan seni Bantengan bisa bertahan sampai saat ini. Dengan metode ini penulis melakukan pencarian atau pengumpulan data dan fakta, melalui observasi, wawancara, dan studi pustaka. Hasil penelitian berupa penafsiran makna dari mantra yang ada dalam tradisi Bantengan bahwa seni Bantengan masih berfungsi dimasyarakat sebagai ritual, hiburan, dan penyatu masyarakat (integritas masyarakat). Sehingga masyarakat daerah Buringan kabupaten Malang masih melakukan kegiatan kesenian tersebut.
\end{abstract}

\section{Kata kunci :kesenian, mantra Jawa, masyarakat Jawa}

\section{Abstract}

This study describes the meaning and function of in depth from a spell performing Bantengan originating from Mojokerto of East Java steel structure. The mantra is covered with mystical, magical formula, mythology, voice, diction, and imagination. The discourse highly Mottled tlah Islamic values in the language of the spell Bantengan. The substance is also attached in the Arabic text of the Mantra Bantengan and produce a new form of special characteristics. Myanmar behind its entanglement applies what functions and meaning so that the public and the audience knows from the spell, what is the function of a ritual, this research uses qualitative research methods with the approach simiotika belonging to Roland Barthes as a reference the meaning of the mantra of Bantengan art, how art can Bantengan development minutes funds at this time. With this method the author searching or collecting data and facts, through observation, interviews, and the study of the literature. Research results in the form of interpretation of the meaning of the mantra that there is in the tradition of Bantengan that Bantengan still works dimasyarakat art as ritual entertainment, and terminating communities (the integrity of the community). So Buringan Malang area community still do art activities.

Keywords :artistry, the mantra of Java, Javanese 


\section{PENDAHULUAN}

Kesenian adalah bagian dari budaya dan merupakan sarana yang digunakan untuk mengekspresikan rasa keindahan dari dalam jiwa manusia. Selain mengekspresikan rasa keindahan dari dalam jiwa manusia, kesenian juga mempunyai fungsi lain. Misalnya, mitos berfungsi menentukan norma untuk perilaku yang teratur serta meneruskan adat dan nilai-nilai kebudayaan. Secara umum, kesenian dapat mempererat ikatan solidaritas suatu masyarakat.Kesenian selalu dikaitkan dengan kebudayaan yang telah berkembamg secara berangsur-angsur dalam kehidupan sosial. Berbicara mengenai pengertian kesenian kita tidak hanya membahas mengenai musik atau tari saja, tetapi melihat unsur lain yang tersembunyi di balik buah kemampuan pikir yang dibarengi dengan kemampuan fisik manusia (Soemaryatmi, 2012:26). Kesenian rakyat selain sebagai wujud budaya aktivitas masyarakat yang berhubungan dengan sosial, di dalamnya juga terkandung makna simbolis yang ingin dicapai oleh masyarakat setempat

Kesenian Bantengan adalah kesenian yang diciptakan untuk mengisi acara pencaksilat saja, tetapi sekarang semakin lama tradisi ini dijadikan sebagai upacara adat penyambutan. Kini menjadi ikon tontonan masyarakat hampir seluruh Jawa Timur. Nama Bantengan berasal dari tokoh utama dari seni tersebut yaitu hewan banteng. Dalam praktiknya, pihak yang menjadi banteng akan kesurupan dan kemudian lepas kendali. Pertunjukan itu sendiri juga dilengkapi dengan tarian-tarian agar menambah semarak. Menurut sejarah, kesenian Bantengan ini sudah sangat lama di Malang. Dari kisah yang ada pada seni dan hubungannya dengan masa lampau, di dapatkan informasi jika seni tersebut sesuai dengan relief Candi Jago di Tumpang. Pada relief tersebut ada macan yang melawan banteng. Sementara di sisi lain juga terdapat tarian dengan topeng banteng. Dalam pertunjukkan Bantengan terdapat berbagai macam nilai-nilai yang terkandung di dalamnya, terutama nilai kebudayaan. Contohnya saja penggunaan sesajian, kemenyan, dan dupa yang merupakan sebuah kebudayaan yang masih dipegang teguh untuk dilakukan. Kebudayaan juga mencerminkan dari sebuah daerah di mana Bantengan tersebut berkembang.

Selain seni Bantengan ada juga seni religi yang terkandung, yaitu seperti halnya pembacaan doa pada saat pembukaan yang dimaksudkan untuk memohon keselamatan kepada Tuhan menurut agama masing-masing dan juga berpamitan kepada leluhur desa tempat diadakannya pertunjukan. Ada juga nilai mistis yaitu ketika seorang penonton yang bersiul akan mengalami kerasukan setan karena konon katanya bersiul itu sama saja melecehkan setan.Ada juga nilai moral yang ada dalam Bantengan, yaitu sebelum dimasukkan pihak ketiga harus terlebih dahulu meminum minuman semacam minuman keras, tetapi saat ini banyak disalahgunakan oleh pemuda zaman sekarang.

Sesuai namanya kesenian Bantengan adalah sebuah seni pertunjukan yang dimainkan oleh tokoh sentral berupa topeng banteng. Dua orang sebagai pelaku banteng, satu pemain berperan sebagai kaki depan sekaligus pemegang kepala banteng dan pengontrol tarian, pemain yang kedua menjadi kaki belakang sekaligus ekornya. Dalam kesenian Bantengan terdapat berbagai macam keunikan yang mempunyai ciri khas pada ritual dilakukan yaitu menyerupai hewan seperi banteng, macan maupun kera.

Tarian rakyat diciptakan oleh suatu masyarakat di tempat berbeda-beda. Dalam pertunjukannya memiliki ciri khas gerakan serta namanya sendiri. Menurut Soemaryatmi (2012:25) tarian rakyat 
merupakan salah satu bentuk seni pertunjukan yang dipentaskan oleh sekelompok waraga masyarakat, secara berkelompok, berpasangan, dengan tema yang beragam. Seni bukan hanya saja seperti foto, lukisan dan lainnya. Jadi, seni itu sangat luas tidak lepas dari kehidupan manusia. Kesenian dan kebudayaan merupakan keindahan yang bisa dinikmati oleh makhluk hidup tidak lain manusia dan manusia sendiri yang menciptakan keindahan tersebut. Kesenian bantengan sangat berkaitan dengan ketenangan sama seperti oalah raga yoga yang berasal dari negara india, perlu ketenangan konsentrasi penuh untuk memanggil arwah bantengan itu sendiri. Mantra jika ditinjau dari segi istilah bisa memiliki arti bunyi, kata, atau kalimat yang diucapkan, dibisikkan, atau dilantunkan dengan cara tertentu untuk tujuan tertentu pula. Mantra diyakini mempunyai kekuatan, sebagai sarana permohonan kepada Tuhan, dan bermanfaat untuk bermacam-macam tujuan tertentu dari para perapalnya.

Dalam kesenian Bantengan terdapat mantra yang dilantunkan. Kesenian tradisional bukan hanya berasal dari daerah Jawa melainkan terdapat banyak kesenian tradisional yang berasal dari Indonesia dan setiap kesenian tersebut akan mencerminkan keunikan dari daerah tersebut. Fungsi dalam makna kesenian Bantengan adalah untuk membentuk perilaku masyarakat untuk selalu hidup dalam nuansa keguyupan, gotong royong, serta selalu menjunjung tinggi rasa persatuan.

Kelebian dari kesenian bantengan ini adalah menciptakan generasi yang tidak melupakan sejarah dan juga kesenian khas tradisional dari daerah yang bertujuan mewariskan kesenian tersebut agar tetap lestari dan dikenal terus menerus. Cara untuk menjaga kesenian tersebut adalah berpartisipasi langsung ke dalam kesenian tersebut.

Berdasarkan uraian tersebut maka masalah yang diangkat dalam penelitian ini yaitu bagaimanacara penggunaan atau penerapan mantra kesenian Bantengan, apa fungsi dari mantra kesenian Bantengan, dan mengapa kesenian Bantengan masih dilestarikan sampai saat ini.

Kesenian Bantengan merupakan salah satu bentuk puisi kuno yang berasal dari Indonesia yang dinamakan kesenian mantra dan kesenian tersebut merupakan sastra lisan yang tidak bisa ditulis dan hanya orang-orang tertentu yang memahaminya tersebut. Suatu karya sastra dapat dikaitkan dengan semiotika. Istilah semiotika berasal dari bahasa Yunani "semeion" yang berarti tanda. Nama lain semiotika adalah semiologi. Bagi para penutur bahasa Inggris dan di lingkungan kebudayaan Amerika nama semiotika sudah menjadi istilah umum.

Barthes (1972) membuat sebuah model sistematis dalam menganalisis makna dari tandatanda melalui analisis. Teori tersebut berangkat dari asumsi bahwa seseorang tidak hanya mengetahui bagaimana isi pesan yang disampaikan melainkan juga bagaimana pesan dibuat, simbol-simbol apa yang digunakan untuk mewakili pesan-pesan yang disampaikan.

Pokok perhatian semiotika adalah tanda. Tanda itu sendiri adalah sebagai sesuatu yang memiliki ciri khusus yang penting. Pertama, tanda harus dapat diamati dalam arti tanda itu dapat ditangkap. Kedua, tanda harus menunjuk pada sesuatu yang lain. Artinya bisa menggantikan, mewakili, dan menyajikan.

\section{METODE PENELITIAN}

Dalam penelitian mantra kesenian Bantengan digunakan jenis penelitian kualitataif yang mempunyai karakteristik, yaitu dengan menyatakan data dalam keadaan yang sewajarnya tanpa 
adanya perubahan dan data yang digunakan bukanlah data tentang angka-angka melainkan kata-kata atau gambaran. Pendekatan yang digunakan dalam penelitian ini adalah pendekatan semiotika.

\section{Data dan Sumber Data}

Sumber data dalam penelitian ini dari sosok seorang orang pintar (dukun) dari kesenian Bantengan. Data yang dianalisis adalah makna dari mantra, dan fungsi menunjukan semiotik mantra kesenian Bantengan. Teknik pengumpulan data yang digunakan dari penelitian ini yaitu 1) mewawancarai seorang orang pintar (dukun) dari kesenian Bantengan tersebut, dan 2) merangkum hasil dari wawancara berdasarkan pengertian mantra dari kesenian Bantengan di daerah Mburing, Malang, Jawa Timur .

\section{Teknik Analisis Data}

Teknik analisis yang digunakan dalam mantra kesenian Bantengan adalah analisis isi. Teknik analisis ini mampu mendeskripsikan atau menggambarkan hasil analisis fungsi dan makna dalam mantra kesenian Bantengan. Penelitian dengan metode analisis isi digunakan untuk menelaah isi dari suatu dokumen. Dalam penelitian ini dokumen yang dimaksud adalah mantra kesenian Bantengan. Penelitian analisis isi ini adalah mendalami fungsi dan makna mantra kesenian Bantengan dan membuat jurnal penelitian yang berisi kutipan-kutipan data yang mendeskripsikan bagaimana semiotika fungsi dan makna.

\section{Desain Penelitian}

Tahapan yang dilakukan peneliti dalam penelitian ini, yaitu (1) mencari sumber data dan informasi, (2) mengalihbahasakan data, (3) memaknai data, dan yang terakhir (4) menarik kesimpulan. Sebagai langkah akhir penelitian untuk mengecek keakuratan atau keabsahan data yang diperoleh.

\section{Teknik Analisis Data}

Teknik yang digunakan ialah melakukan wawancara, menalaah secara teliti, dan mengadakan diskusi bersama teman serta ahli yang mampu memahami objek penelitian. Hasil penelitian yang diharapkan (1) mampu memaknai makna dan fungsi makna Bantengan di daerah Mburingan yang menjadi tradisi dalam masyarakat dan anak didik sekolah agar tidak punah dari perdapan sosial, dan (2) mampu memaparkan fungsi sesungguhnya tradisi dari Bantengan itu sendiri bagi masyrakat yang belum mengetahui khususnya masyarakat Mburingan dan daerah Malang.

\section{HASIL PENELITIAN DAN PEMBAHASAN}

Kesenian Bantengan merupakan kesenian komunal yang melibatkan banyak orang dalam setiap pertunjukannya. Seperti halnya sifat kehidupan hewan banteng, yaitu hidup berkelompok (koloni), kebudayaan Bantengan ini membentuk perilaku masyarakat yang menggelutinya untuk selalu hidup dalam keguyuban, gotong royong dan menjunjung tinggi rasa persatuan kesatuan. Sebuah kesenian itu muncul akibat dari kebiasaan suatu komunitas dan kesenian Bantengan lahir dari sebuah budaya pedesaan dimana di dalamnya terdapat sebuah komunitas yaitu pencak silat. Jadi, dalam kesenian Bantengan ini sama sekali tidak terdapat unsur-unsur politik.

Pada masa reformasi kesenian Bantengan kembali bangkit, dengan adanya kebebasan untuk 
berekspresi. Seni Bantengan tumbuh dan berkembang seiring dengan pekembangan zaman, dan muncul pula berbagai versi kesenian Bantengan. Sebagai perbandingan, kesenian Bantengan yang terkenal ada di dua tempat yaitu di daerah Batu Malang dan yang kedua berasal dari Pacet tepatnya di Dusun Claket.Jika pementasan Bantengan di Claket terdiridari Pencak Silat, Gulungan Duri Salak, Bantengan, Macanan, Topengan, dan musik gamelan lengkap. Pementasan dilakukan atas undangan-undangan dari warga maupun pejabat setempat, seperti acara perkawinan, ruwat desa, pesta kemerdekaan RI dan sebagainya. Beliau tidak pernah mematok harga, tetapi itu semua tergantung keikhlasan dari para undangan. Kini kesenian ini masih dalam perbincangan Dinas Pemuda, Olahraga,dan Pariwisata Mojokerto untuk dijadikan sebagai ikon Kota Mojokerto. Hal lain tampak sangat berbeda dengan kehidupan para anggota kelompok Bantengan yang ada di Batu Malang.

Salah satu wadah kesenian Bantengan yang terbesar berada di Batu Malang. Wadah kesenian Bantengan yang terkenal adalah Bantengan Nusantara. Wadah ini adalah penggiat acara kesenian Bantengan yang diselenggarakan setiap tahun. Bantengan Nusantara ini ingin menampilkan kesenian Bantengan yang asli, yang terdiri dari Pencak Silat sebagai pembukaan, Bantengan, Macanan, dan musik yang hanya terdiri dari kendang dan jidor. Hal ini disengaja untuk menampilkan keaslian dari kesenian Bantengan dan jika ditambahkan unsur-unsur lain itu hanya dalam acara-acara tertentu seperti festival dan sebagainya. Pernah suatu hari diadakan festival Seni Trans (kesurupan) dari seluruh dunia yang diadakan di Batu Malang. Bantengan berkolaborasi dengan Seni Trans seperti dari Thailand, Philipina, Australia, dan masih banyak lagi negara lainnya. Namun, kesenian Bantengan yang ditampilkan tidak kalah menarik jika dibandingkan dengan kesenian trans dari negara lain. Tidak seperti di Mojokerto, Bantengan di Batu Malang tidak mendapat pengakuan dari pemerintah setempat, dan juga sering tidak mendapat izin untuk pementasan, sehingga penyelenggaraan atau pementasan berasal dari dana pribadi. Meskipun sering tidak mendapatkan izin kelompok ini tetap tampil. Pementasan kesenian Bantengan dilakukan berdasarkan sistem kekeluargaan tanpa upah, meskipun banyak dari kelompok lain yang mematok harga. Kostum-kostum atau pakaian semua diperoleh dari sponsor atau dana anggota kelompok.

Dalam pertunjukkan Bantengan terdapat berbagai macam nilai-nilai yang terkandung di dalamnya, terutama nilai kebudayaan. Contohnya saja penggunaan sesajian, kemenyan, dan dupa yang merupakan sebuah kebudayaan yang masih dipegang teguh untuk dilakukan. Kebudayaan juga mencerminkan dari sebuah daerah dimana Bantengan tersebut berkembang.

Selain seni Bantengan ada juga seni religi yang terkandung, yaitu seperti halnya pembacaan doa pada saat pembukaan yang dimaksudkan untuk memohon keselamatan kepada Tuhan menurut agama masing-masing dan juga berpamitan kepada leluhur desa tempat diadakannya pertunjukkan. Ada juga nilai mistis yaitu ketika seorang penonton yang bersiul akan mengalami kerasukan setan karena konon katanya bersiul itu sama saja melecehkan setan. Ada juga nilai kebenaran dalam seni ini. Dalam alur ceritanya tokoh bantengan akan menyerang dan melawan tokoh macan yang memiliki arti bahwa masyarakat pribumi tidak bisa diam dengan penjajah yang memakan hak masyarakat. Hal ini berarti bahwa kebenaran suatu saat pasti akan mengalahkan kejahatan.

Kesenian Bantengan pada zaman dahulu merupakan tradisi yang sangat kental akan nilainilai yang terkandung dalam kesenian tersebut dalam prospek untuk mendatangkan keberkahan di dalam desa asal usul kesenian Bantengan. Pada sebuah pementasan Bantengan zaman dahulu 
terdapat berbagai runtutan dan aturan penyelenggaraan kesenian Bantengan. Aturan-aturan kesenian Bantengan zaman dahulu selalu dipakai sebagai patokan penyelenggaraan kesenian Bantengan saat ini.

Berbeda dengan zaman sekarang, dengan perkembangan zaman kesenian Bantengan lebih terlihat sebagai kesenian yang memperlihatkan banyak hal yang menekankan kemistisan seperti kesurupan. Kesurupan ini ditekankan supaya penonton merasa terhibur dan tertarik dengan kesenian Bantengan ini. Pada setiap pementasan Bantengan salah satunya dalam acara karnaval, Bantengan hanya terlihat dari segi mistis, sedangkan aturan-aturan atau aturan-aturan yang terdapat dalam kesenian Bantengan tidak dijalankan keseluruhan. Iringan musik dan tarian yang khas dari kesenian Bantengan juga dipentaskan hanya sekilas atau dengan durasi pendek. Terkadang iringan musik tidak terdengar dikarenakan iringan musik dan orang yang memainkan Bantengan terpisah dalam acara karnaval tersebut.

Dari banyaknya nilai yang terkandung dalam kebudayaan Bantengan, dimasa kini telah terjadi pergeseran pandangan kebanyakan masyarakat. Penonton tidak mengindahkan ataupun tidak mengetahui nilai-nilai tersebut karena mereka hanya mengetahui dan menginginkan hal-hal yang berbau mistis. Seperti halnya kesurupan dan sesuatu yang dinamakan cekelan (pegangan). Cekelan yang dimaksudkan disini adalah makhluk halus yang memiliki berbagai macam tipe dan hal itu menjadi daya tarik sendiri bagi sebagian kalangan masyarakat. Nilai seni semakin tidak diindahkan sehingga semakin lama pakem dari seni Bantengan semakin dilupakan yang kemudian pada akhirnya Bantengan hanyalah menjadi tontonan yang tidak memiliki nilai apa-apa.

Mantra adalah sekumpulan kata yang dipercaya bisa merubah keadaan spiritual. Dari hal tersebut sehingga munculah mantra pada kesenian Bantengan. Mantra tersebut diciptakan oleh sesepuh terdahulu yang mempunyai fungsi dan makna.Kesenian sastra lisan memiliki sisi yang jika dinalar dengan akal sehat tidak akan bisa masuk akal, tetapi pada kenyataannya seni tersebut dapat memanggil makhluk lain yang bukan manusia yaitu makhluk gaib. Pertunjukan Bantengan ini sendiri mempunyai batasan-batasan yang sering disebut pakem-pakem. Namun, pada zaman sekarang para pendekar muda sering halnya melanggar pakem tersebut. Oleh karena itu, solusi terbaik untuk menghindari penyalahgunaan kebudayaan haruslah ditanamkan rasa cinta dan kepemilikan terhadap budaya tersebut agar tidak terjadi pelanggaran pakem-pakem yang telah ditentukan.

Untuk mengobati masalah-masalah tersebut, perlulah tindak lanjut terhadap penyalahgunaan budaya oleh seniman dan budayawan yang mempunyai wewenang dan diberikan sangsi agar penyalahgunaan tersebut tidak diulangi kembali. Setiap permasalahan tersebut haruslah diselesaikan dengan baik-baik tanpa adanya pertengkaran atau perselisihan. Maka untuk budayawan dan seniman harus memberi nasihat kepada pendekar-pendekar agar lebih mencintai budaya Bantengan tersebut.

Bantengan merupakan sebuah seni tradisi khas Jawa Timur yang mengandung unsur kesurupan (trance) di dalamnya sebagai bukti bahwa hal ini merupakan hasil dari manifestasi kepercayaan mereka mengenai hal-hal transendental yang berada disekeliling mereka, seperti pada Tuhan, roh-roh suci, arwah nenek moyang, dewa-dewi, roh penunggu tempat (danyang). Dalam melakukan interaksi dengan hal trasendental di sekeliling mereka, maka digunakanlah sesaji sebagai simbol komunikasi serta sebagai simbol manifestasi kepercayaan mereka. Hal ini dikarenakan sesaji merupakan salah 
satu bentuk fisik dari simbol kepercayaan mereka. Selain itu, dalam kesenian tradisi Jawa, khususnya kesenian Bantengan, sesajen memiliki keterkaitan erat dengan prosesi trance atau kesurupan (kalap). Setiap acara dalam Bantengan terdapat pembukaan yang harus dilakukan untuk meminta doa restu dan pamit. Kesenian Bantengan identik dengan pihak ketiga maka dalam pembukaan mulailah mengeluarkan mantra-mantra untuk pihak ketiga agar ikut serta.

Setelah menyelesaikan mantra-mantra dan doa, dimulailah pertunjukan yang diawali dengan pencak silat, kemudian keluarlah banteng, macan serta monyet untuk menampilkan pertunjukan mereka yang dibantu oleh pihak ketiga. Saat penutup, para pendekar mengucapkan terima kasih, dan memohon maaf atas kesalahan kepada para penonton, dan leluhur dan tak lupa pihak ketiga dalam penutupan di kembalikan ke tempatnya.

Dalam pandangan Islam, ini menjadi salah satu yang sering kali banyak dipertanyakan oleh orang banyak kerena pada ritual Bantengan terdapat kesurupan (trance) di mana roh-roh halus dipanggil untuk ditransfer ke dalam tubuh manusia yang memainkan Bantengan. Ada sebagian yang mempercayai adanya hal seperti itu, tetapi tidak banyak juga yang tidak mempercayai adanya hal tersebut. Di dalam alam bebas ini terdapat alam ghaib yang dihuni oleh makhuk tak kasat mata, misalnya saja, jin atau setan yang pada umumnya keduanya tergolong makhluk yang durhaka kepada Tuhan.

\section{Makna Mantra Kesenian Bantengan dari Seorang Dukun}

Pada mantra Jawa kesenian Bantengan yang terdapat cara pengucapan yakni "Lailaanta subhanakka inikuntum minat dzolimin danyang lor kidul etan kulon ketemu kalap tak repno tengahe latar sun mata ajiku ajine wong sak jagat tak ajine nang awak insun kulo." Arti dari makna tersebut ke bahasa Indonesia adalah ya Allah, tidak ada Tuhan selain Engkau. Maha suci Engkau. Sungguh aku ini termasuk orang-orang yang zalimarwah dari arah barat, timur, selatan, dan utara bertemu. Saya kumpulkan di tengah lapangan di depan mata saya. Jimat saya dan jimat orang terdahulu saya pakai jimatnya untuk badan saya.

Makna yang terkandung pada mantra kesenian Bantengan ini adalah orang yang memainkan Bantengan dia harus membaca mantra tersebut untuk mendapatkan ridho dari Allah Swt. agar arwah yang berada di dalam tubuh penari tidak merusak atau mengganggu tubuh dari penari tersebut.

\section{Fungsi Mantra Kesenian Bantengan bagi Masyarakat Desa Mburing}

Mantra kesenian Bantengan juga merupakan ajaran bahasa Jawa tentang adanya makhluk selain manusia. Fungsi pengucapan dari mantra tersebut adalah untuk memanggil roh halus untuk merasuki dari dua penari Bantengan terbut agar bisa mempertunjukan tarian yang sangat indah. Bagi masyarakat Desa Mburing sendiri kesenian Bantengan tersebut menjadi ajang tontonan untuk setiap minggunya. Maka dari itu mengapa kesenian Bantengan masih ada atau masih dilestarikan hingga saat ini.

\section{PENUTUP}

Berdasarkan hasil penelitian dapat disumpulkan bahwa setiap mantra yang disakralkan oleh masyarakat setempat memiliki makna dan fungsi tersendiri sesuai dengan apa yang diyakini 
masyarakat tersebut.

Di zaman sekarang masyarakat kurang begitu memperhatikan kesenian-kesenian terdahulu, seperti kesenian Bantengan. Keseninan Bantengan digelar hanya di desa-desa atau di pinggiran kota saja. Dari hasil wawancara kepada seorang spiritual atau seorang dukun diketahui bahwa mantra kesenian Bantengan ini memiliki makna dan fungsi jika seorang menggunkan baik dan benar. Mantra ini akan meminbulkan efek positif bagi sekelilingnya

Mantra tersebut mempunyai banyak sekali fungsi. Fungsi utama dari mantra tersebut adalah memanggil roh halus terdahulu agar memasuki raga dari pemain atau penari Bantengan tersebut agar menampilkan tarian yang sangat menyerupai banteng.

\section{DAFTAR PUSTAKA}

Barthes, R. 1972. Membedah Mitos-Mitos Budaya Massa: Semiotika atau Semiologi Tanda, Simbol, dan Representasi. (M. Ikramullah, Ed.) Yogyakarta: Jalasutra.

Soemaryatmi. 2012. Dampak Akulturasi Budaya pada Kesenian Rakyat. Jurnal Seni \& Budaya Panggung Vol. 22, No. 1, Januari - Maret 2012. 